\title{
Climate changes health
}

\author{
Nino Künzli
}

Published online: 16 February 2010

(C) Swiss School of Public Health 2010

As pointed out by McMichael (McMichael et al. 2009) the absence of health indicates a serious blind spot in the climate change (CC) discussion. This issue of the journal assembles a series of articles under the heading of Climate Changes Health. In her editorial, Sari Kovats makes the point that health research in the CC domain is suffering from the legacy of reductionism in the health sciences and its clinical bias (Kovats 2009). One may claim that this is true for a wide range of public health issues and research agendas, but this legacy becomes particularly evident in light of the new challenges that $\mathrm{CC}$ health research faces. Overcoming reductionism by moving out of the laboratory into the complexities of real life of people is both a wellknown challenge and success of epidemiological research methods. Modern epidemiology combines the world of molecules, proteins, and genes with peoples' ever changing life styles, environments, cultures, social factors and health care systems to understand how public health is driven by the interactions among all these factors. The challenge of the research agenda (and policy making) on climate change and health will be to connect the endogenous dots of a 'systems biology' perspective with the exogenous spheres

This paper belongs to the special issue "Climate changes health".

Nino Künzli is Deputy Director of the Swiss Tropical and Public Health Institute, an associate Institute of University of Basel, and head of its Department of Epidemioloy and Public Health. His research focus is on understanding the environmental causes of health, in particular air pollution, and its implications on public health.

N. Künzli (凹)

Swiss Tropical and Public Health Institute,

Socinstrasse 57, P.O. Box 4002, Basel, Switzerland

e-mail: Nino.Kuenzli@unibas.ch of the socio-cultural and physical environment and to put it in the context of trans-generational changes due to climate change. The latter will call for a broad 'systems approach', beyond people and populations. Will we succeed to integrate this further dimension of global changes due to $\mathrm{CC}$, expected to happen gradually, over decades if not centuries to understand its implication on health and to properly adapt health policies? While knowledge and facts do not necessarily lead to healthy public policies (van Dijk 2008), we certainly need good research to at least understand what the right policies may possibly be. As discussed by Xun et al., development of adequate methods is crucial (Xun et al. 2009).

However, the challenge to understand the long-term health implications of $\mathrm{CC}$ should not distract from taking action on the by far strongest causes of morbidities, mortality, and poor quality of life, namely socioeconomic hardship, deprivation, and poverty (Marmot 2009). CC will hit the socially deprived hardest (Gill and Stott 2009). If societies continue to be ignorant of or unable to resolve the paradox where the role of social factors in the etiology of disease is well established while evidence and research are lacking on what works to change the social determinants of health (McQueen 2009), the ability to adapt public health policy to the challenges of $\mathrm{CC}$ will be jeopardized. Mortality and most common diseases are already two times higher among the socially deprived (Koskinen and Puska 2009), but CC may further amplify these known inequalities in health within and across populations (MadarasovaGeckova 2009). On the other side, the CC challenges and complexities should neither distract from the fact that a range of $\mathrm{CC}$ abatement strategies, namely the reduction of fossil fuel combustion, will have very immediate public health consequences (McMichael et al. 2009). Well selected $\mathrm{CC}$ policies may result in very substantial and rather 
immediate ancillary health benefits (Kunzli and Perez 2009; McMichael et al. 2009).

\section{References}

Gill M, Stott R (2009) Health professionals must act to tackle climate change. Lancet 374:1953-1955

Koskinen S, Puska P (2009) From social determinants to reducing health inequalities. Int J Public Health 54:53-54

Kovats S (2009) Research on climate change and health: looking ahead. Int J Public Health. doi:10.1007/s00038-009-0093-Z

Kunzli N, Perez L (2009) Evidence based public health-the example of air pollution. Swiss Med Wkly 139:242-250
Madarasova-Geckova A (2009) Can research contribute to the public's capacity for activities that reduce socioeconomic inequalities in health? Int J Public Health 54:201-202

Marmot M (2009) Social determinants and adolescent health. Int J Public Health 54(Suppl 2):125-127

McMichael A, Neira M, Bertollini R, Campbell-Lendrum D, Hales S (2009) Climate change: a time of need and opportunity for the health sector. Lancet

McQueen DV (2009) Three challenges for the social determinants of health pursuit. Int J Public Health 54:1-2

van Dijk JP (2008) Public health facts-why don't they lead to healthy public policy? Int J Public Health 53:121-122

Xun WW, Khan AE, Michael W, Vineis P (2009). Climate change epidemiology: methodological challenges. Int J Public Health. doi:10.1007/s00038-009-0091-1 